\title{
New Homoptera from the Early Cretaceous of Buryatia with notes on the insect fauna of Khasurty
}

\author{
Новые Homoptera из раннего мема Бурятии с замечаниями по \\ энтомофауне Хасурты
}

\author{
Dmitry E. Shcherbakov \\ А.Е. Щербаков
}

Borissiak Paleontological Institute, Russian Academy of Sciences, Moscow, Russia; dshh@narod.ru Палеонтологический институт им. А.А. Борисяка РАН, Москва, Россия.

KEY WORDS: Hemiptera, Auchenorrhyncha, Cicadomorpha, Hylicellidae, Sternorrhyncha, Psyllomorpha, Liadopsyllidae, forewing, pterostigma, nodal line, phylogeny, fossil, aquatic insects, terrestrial insects, aphids, relicts, paleolake, temperate rainforest.

КЛЮЧЕВЫЕ СЛОВА: Hemiptera, Auchenorrhyncha, Cicadomorpha, Hylicellidae, Sternorrhyncha, Psyllomorpha, Liadopsyllidae, переднее крыло, птеростигма, нодальная линия, филогения, ископаемые, водные насекомые, наземные насекомые, тли, реликты, древнее озеро, дождевой лес умеренного климата.

ABSTRACT. Reticycla drosopoulosi gen. et sp.n. from the Early Cretaceous of Khasurty, Buryatia is described in Hylicellidae Vietocyclinae (Cicadomorpha). The genus Jiphara Ren, 1995 from the Early Cretaceous of China is transferred from Pereboriidae to Vietocyclinae. Stigmapsylla klimaszewskii gen. et sp.n., Liadopsylla (Basicella) lautereri subgen. et sp.n. and $L$. (B.) loginovae sp.n. from Khasurty are described in Liadopsyllidae s. str. (Psyllomorpha). Free $\mathrm{CuA}$ base and nodal line are first reported in forewings of Mesozoic Psylloidea. Two species from Cretaceous ambers are transferred from Liadopsylla to Cretapsylla gen.n.: C. apedetica (Ouvrard, Burckhardt et Azar, 2010) comb.n., C. hesperia (Ouvrard et Burckhardt, 2010) comb.n. The family Malmopsyllidae is resurrected from synonymy with Liadopsyllidae and divided into Malmopsyllinae, stat.n. and Miralinae subfam.n. (for Mirala Burckhardt et Poinar, 2020 from Burmese amber). The insect assemblage and other fossil finds from Khasurty as well as the age and paleoenvironment of this fauna are briefly discussed.

РЕЗЮМЕ. Reticycla drosopoulosi gen. et sp.n. из раннего мела местонахождения Хасурты, Бурятия, описан в Hylicellidae Vietocyclinae (Cicadomorpha). Род Jiphara Ren, 1995 из раннего мела Китая перенесён из Pereboriidae в Vietocyclinae. Stigmapsylla klimaszewskii gen. et sp.n., Liadopsylla (Basicella) lautereri subgen. et sp.n. и $L$. (B.) loginovae sp.n. из Хасурты описаны в Liadopsyllidae s. str. (Psyllomorpha). Свободное основание $\mathrm{CuA}$ и нодальная линия впервые отмечены в передних крыльях мезозойских Psylloidea. Два вида из меловых янтарей перенесены из Liadopsylla в Cretapsylla gen.n.: C. apedetica (Ouvrard, Burckhardt et Azar, 2010) comb.n., C. hesperia (Ouvrard et Burckhardt, 2010) comb. n. Семейство Malmopsyllidae восстановлено из синонимии с Liadopsyllidae и разделено на Malmopsyllinae, stat.n. и Miralinae subfam.n. (для рода Mirala Burckhardt et Poinar, 2020 из бирманского янтаря). Кратко обсуждаются комплекс насекомых и другие ископаемые находки из Хасурты, а также возраст и среда обитания этой фауны.

In 2003, Olga Minina and Andrey Filimonov (Geological Institute, Siberian Branch, RAS) discovered a new Late Mesozoic locality of insects and other fossils near the Khasurty (Hasurtyi) River, SW Buryatia and donated the insect fossils to the Paleontological Institute RAS (PIN). Field parties of the Arthropoda Lab (PIN) visited this site in 2004, 2009, 2014 and 2019 and collected about 7000 total insects along with other plant and animal fossils. Several taxa from Khasurty were described in Bryophyta [Ignatov, Shcherbakov, 2011; Mamontov, Ignatov, 2019], Cladocera [Kotov, 2009], Coleoptera [Legalov, 2010; Gratshev, Legalov, 2014; Strelnikova, 2019], Plecoptera [Sinitshenkova, 2011], Hymenoptera [Kopylov, 2011; Kopylov, Rasnitsyn, 2014; etc.], Diptera [Blagoderov, Lukashevich, 2013; Lukashevich et al., 2020; etc.], Ephemeroptera [Sinitshenkova, 2017], Neuroptera [Khramov, 2018], and Trichoptera [Ponomarenko et al., 2009; Sukatsheva, Vasilenko, 2019]. However, the

How to cite this article: Shcherbakov D.E. 2020. New Homoptera from the Early Cretaceous of Buryatia with notes on the insect fauna of Khasurty // Russian Entomol. J. Vol.29. No.2. P.127-138. doi: 10.15298/ rusentj.29.2.02 
rich and peculiar biota of Khasurty is still insufficiently studied. The entomofauna of Khasurty and its age are discussed below.

The Khasurty insect assemblage is numerically codominated by phantom midges (Chaoboridae) and their aquatic immatures, as well as winged adult aphids. Homoptera other than aphids are rather rare and moderately diverse. The more numerous of them are primitive Peloridioidea (Karabasiidae), primitive Cicadomorpha (Hylicellidae), and Psyllomorpha, whereas other Auchenorrhyncha families are less common. A new genus of Hylicellidae, belonging to the Jurassic-Early Cretaceous subfamily Vietocyclinae, and a new genus and a new subgenus of the psyllomorph Jurassic-Cretaceous family Liadopsyllidae are described below from Khasurty.

The material is deposited at Borissiak Paleontological Institute, Russian Academy of Sciences, Moscow (PIN). Photographs were taken using a Leica M165C stereomicroscope with a Leica DFC425 digital camera. Scanning electron micrographs of uncoated specimens were obtained with TESCAN VEGA microscope using backscattered electron detector.

\section{Infraorder Cicadomorpha Evans, 1946}

Family Hylicellidae Evans, 1956

Subfamily Vietocyclinae Shcherbakov, 1988

REVISED DIAGNOSIS. Tegmen: several postnodal $\mathrm{R}$ branches arising from RA and sometimes from $\mathrm{dSc}$; at least 2 $r-m$ crossveins; at least 4 terminations of $\mathrm{M}$; $\mathrm{M}$ fused with $\mathrm{CuA}$ beyond basal cell in one point or for a short distance. Hind wing: ir crossvein absent; RP and M usually fused for a distance in place of $r-m$ crossvein (rarely $r-m$ developed); at least 3 terminations of $\mathrm{M} ; \mathrm{CuA} 2$ proximally arched posteriad, distally converging with $\mathrm{CuA} 1$. Postclypeus large, swollen, with transverse muscle impressions. Antennal flagellum thick, segmented. Pronotum covering entire mesonotum except for scutellum, transversely striate.

COMPOSITION. Cycloscytina Martynov, 1927, Vietocycla Shcherbakov, 1988, Jiphara Ren, 1995, Reticycla gen.n.

DISTRIBUTION. Jurassic and Early Cretaceous of Asia.

\section{Reticycla Shcherbakov, gen.n.}

TYPE SPECIES: Reticycla drosopoulosi Shcherbakov, sp.n.

DIAGNOSIS. Distinct from the other genera in the $\mathrm{M}$ in tegmen fused with $\mathrm{CuA}$ for a short distance beyond the basal cell (in one point in other genera), basal cell strongly tapered towards apex, and 2-3 (or 1 forked) postnodal $\mathrm{R}$ branches arising from dSc (0 or rarely 1 branch on dSc in Vietocycla and Cycloscytina, 4 or more in Jiphara). Similar to Cycloscytina and distinct from Vietocycla in the fore legs not modified, and the ovipositor almost not extending beyond the tip of abdomen and no longer than the width of tegmen (the body structure is unknown in Jiphara).

COMPOSITION. Type species.

ETYMOLOGY. From Latin retia (net) and cyclus (ring); gender feminine.

\section{Reticycla drosopoulosi Shcherbakov, sp.n.} Figs 1-12.

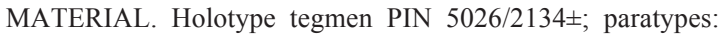
tegmina PIN 5026/2133 \pm , 5340/516 \pm , 1356 \pm ; hind wing PIN 5340/ 1349; females PIN 5340/521, 1355; Khasurty, $10 \mathrm{~km} \mathrm{~S}$ of Tsakir, Zakamensk district, SW Buryatia, Russia; Lower Cretaceous.

DESCRIPTION. Tegmina $10.8-12.5 \mathrm{~mm}$ long, more or less elongate (2.4-2.9:1). Costal margin arched evenly or more so near base. Basal cell strongly tapered distally and deflected posteriad from longitudinal axis of tegmen $(\mathrm{CuA}$ base arched). Prenodal R branches faint. Branches of RA with 9-10, RP with 4-5, M with 4-8, CuA with 3-4 terminations, all these together with 22-26 terminations and about twenty or more crossveins. Tegmina with distinct colour pattern: pale, dark-margined markings at anterior and posterior nodus, and either small pale spots on dark background or darkened main vein stems on pale background; base of tegmen darkened. Hind wing about $10 \mathrm{~mm}$

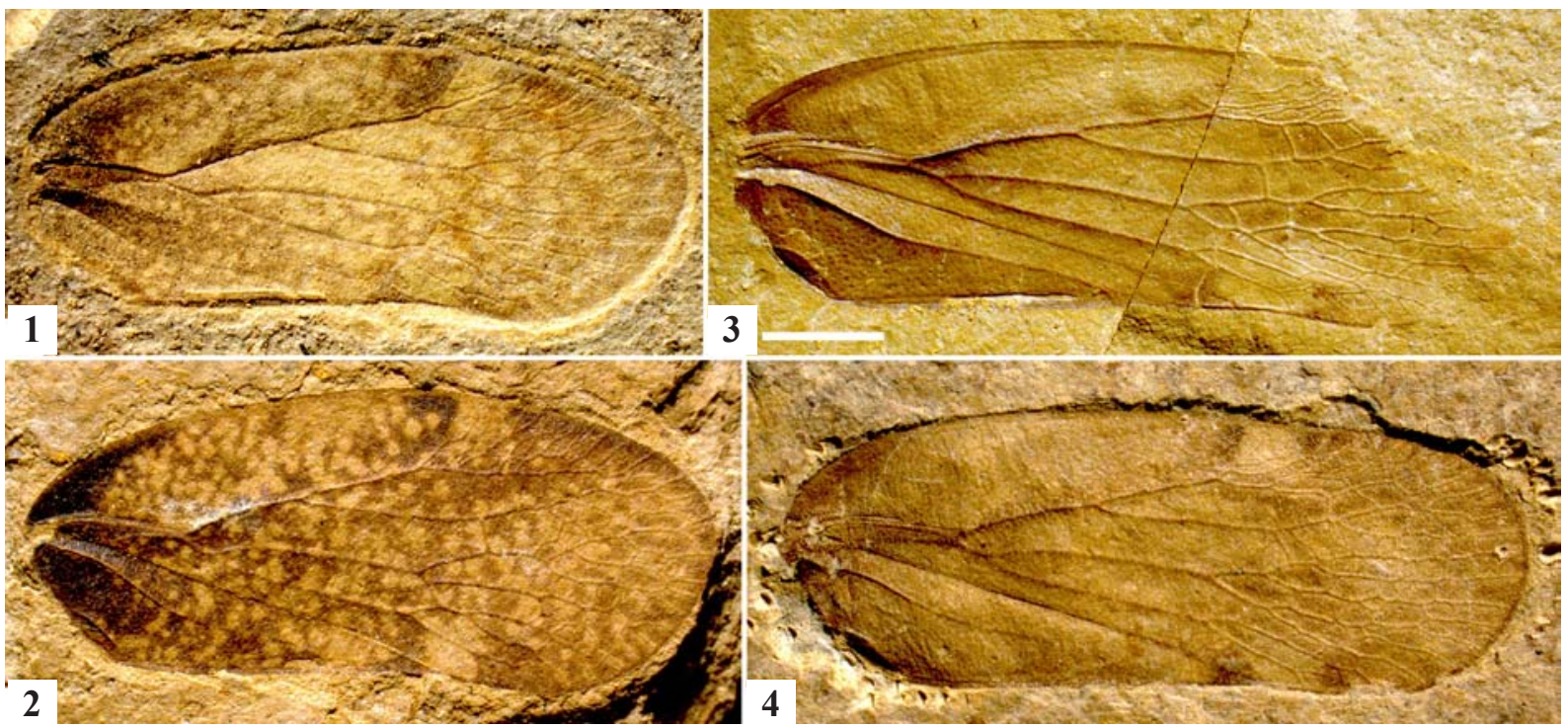

Figs 1-4. Reticycla drosopoulosi gen. et sp.n., tegmina; Khasurty, Lower Cretaceous: 1 - holotype; $2-4$ - paratypes PIN (photographs mirrored): $2-5340 / 1356 ; 3-5026 / 2133 ; 4-5340 / 516$. Scale bar $2 \mathrm{~mm}$ for all figures.

Рис. 1-4. Reticycla drosopoulosi gen. et sp.n., передние крылья; Хасурты, нижний мел: 1 - голотип; 2-4 - паратипы ПИН (фото перевёрнуты зеркально): $2-5340 / 1356 ; 3-5026 / 2133 ; 4-5340 / 516$. Длина масштабной линейки 2 мм для всех рис. 
long, $r-m$ developed, $\mathrm{M}$ with 3 terminations, $\mathrm{CuA} 2$ characteristically bent. Female body $11.3-13.0 \mathrm{~mm}$ long. Postclypeus large, much inflated, with transverse muscle impressions. Antenna length subequal to head height; flagellum of about ten elongate segments, proximal 4 times, distal 3 times as long as wide. Pronotum with anterolateral depressions, in posterior zone with rough transverse striae. Fore legs apparently not modified. Hind tibiae slender, with minute widely spaced lateral teeth and apical pecten. Ovipositor almost not extending beyond tip of abdomen, no longer than tegmen width; inner valvulae with serrate section near apex.

VARIATION. Of the four isolated tegmina, two are slightly shorter, less elongate, darker and pale-speckled (holotype and PIN 5340/1356), and two others are a bit longer, more elongate and paler with reduced specked pattern (PIN 5026/2133, 5340/516). The degree of the costal margin convexity, number of postnodal $\mathrm{R}$ branches on $\mathrm{dSc}$, position of $\mathrm{M}$ fork, relative length of the postnodal part and development of pale areas are also somewhat variable. By analogy with Vietocycla peregrina Shcherbakov, 1988, showing sexual dimorphism in size and colour pattern of tegmina, I tentatively consider all the specimens as representing the two sexes of $R$. drosopoulosi. Another possibility is colour polymorphism, as in some spittlebugs and leafhoppers [Drosopoulos et al., 2010; Tishechkin, 2012].
ETYMOLOGY. To the memory of a Greek expert in Auchenorrhyncha, Sakis Drosopoulos (1944-2014).

Infraorder Psyllomorpha Becker-Migdisova, 1962

Superfamily Psylloidea Latreille, 1807

Family Liadopsyllidae Martynov, 1927, s.str.

REVISED DIAGNOSIS. Forewing: Costal space elongate, usually ribbon-like. $\mathrm{M}$ forked; $\mathrm{CuA}$ fork triangular, $\mathrm{CuA} 2$ not recurrent or very short. $\mathrm{R}$ bifurcation at $<1 / 3$, $\mathrm{R}+\mathrm{M}+\mathrm{CuA}$ bifurcation at $<1 / 5$ wing length. Pterostigma usually present, but often poorly developed.

COMPOSITION. Liadopsylla Handlirsch, 1921, Stigmapsylla Shcherbakov, gen.n., Cretapsylla Shcherbakov, gen.n.

DISTRIBUTION. Jurassic and Cretaceous of Eurasia and North America.

\section{Stigmapsylla Shcherbakov, gen.n.}

TYPE SPECIES: Stigmapsylla klimaszewskii Shcherbakov, sp.n.

DIAGNOSIS. Distinct from the other genera in the combination of well-developed, dark pterostigma, markedly arched costal margin, and basally narrow $\mathrm{R}$ fork in the forewing.

COMPOSITION. Type species.

ETYMOLOGY. From Greek stigma (mark, spot) and the generic name Psylla; gender feminine.
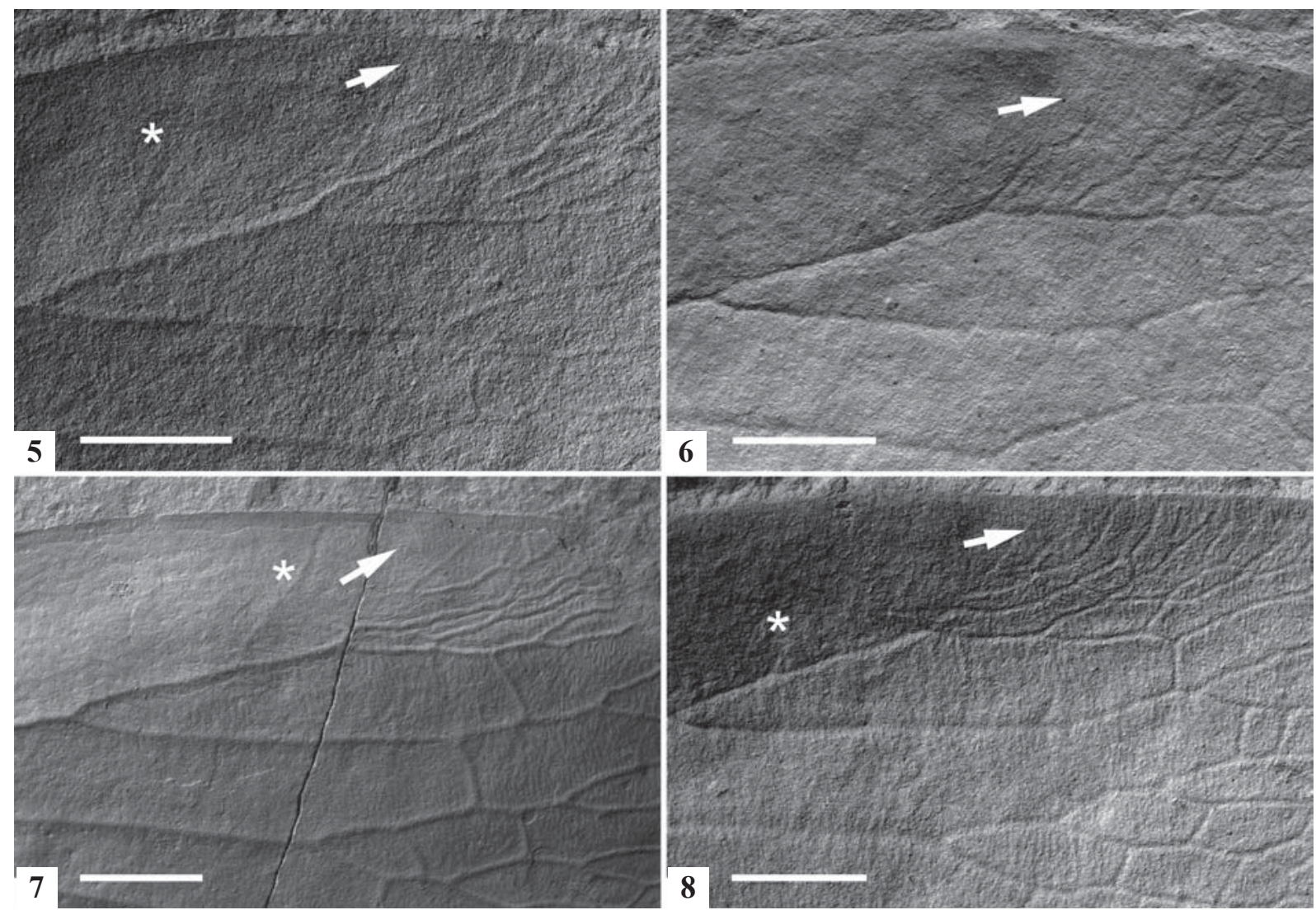

Figs 5-8. Reticycla drosopoulosi gen. et sp.n., nodal area of tegmen, SEM; Khasurty, Lower Cretaceous: 5 - holotype; 6-8 - paratypes PIN (images mirrored): 6 -5340/1356; 7 - 5026/2133; 8 - 5340/516; arrow — dSc; asterisk — prenodal R branch. Scale bars $1 \mathrm{~mm}$ in all figures.

Рис. 5-8. Reticycla drosopoulosi gen. et sp.n., нодальная область переднего крыла, СЭМ; Хасурты, нижний мел: 5 - голотип; 68 — паратипы ПИН (изображения перевёрнуты зеркально): 6 -5340/1356; 7 - 5026/2133; 8 - 5340/516; стрелка — dSc; звёздочка - пренодальная ветвь R. Длина масштабной линейки 1 мм на всех рис. 
Stigmapsylla klimaszewskii Shcherbakov, sp.n. Fig. 13.

MATERIAL. Holotype forewing (incomplete at RP apex) and underlying hind wing PIN 5340/1378 \pm ; Khasurty, $10 \mathrm{~km} \mathrm{~S}$ of Tsakir, Zakamensk district, SW Buryatia, Russia; Lower Cretaceous.

DESCRIPTION. Forewing $2.8 \mathrm{~mm}$ long, rather elongate (2.3:1), widened up to before nodus, narrowly rounded apically. Nodal line absent. Costal margin arched, more deeply in the middle; costal space moderately wide (4.8:1). Pterostigma distinct, subtriangular, with sharp, anteriorly recurrent basal boundary. $\mathrm{R}+\mathrm{M}+\mathrm{CuA}$ dividing before $1 / 5$, $\mathrm{R}$ stem before $1 / 4$, and $\mathrm{M}+\mathrm{CuA}$ about $1 / 3$ wing length. $\mathrm{R}$ fork basally narrow, with nearly straight RA and proximal RP. $\mathrm{M}+\mathrm{CuA}$ stem thrice longer than $\mathrm{R}$ stem and slightly longer than $\mathrm{R}+\mathrm{M}+\mathrm{CuA}$. $\mathrm{M}$ stem equal to $\mathrm{M} 2$ and $\mathrm{x} 1.6$ as long as $\mathrm{CuA}$ stem, $\mathrm{M}$ fork wide (2.4:1). CuA1 x1.6 as long as $\mathrm{CuA}$ stem and $\mathrm{x} 4$ as $\mathrm{CuA} 2$. Clavus rather wide, with arched posterior margin; Pcu+1A distally not running along the margin and joining it near clavus apex. Veins and pterostigma dark, membrane pale. Hind wing delicate, much shorter and narrower than forewing, $\mathrm{R}-\mathrm{RA}$ and $\mathrm{CuA}$ are visible.

ETYMOLOGY. To the memory of a Polish expert in psyllids, Sędzimir Maciej Klimaszewski (1937-2001).

\section{Liadopsylla Handlirsch, 1921}

TYPE SPECIES: Liadopsylla geinitzi Handlirsch, 1921

REVISED DIAGNOSIS. Forewing: Costal margin feebly and/or evenly convex; costal space elongate, more or less ribbon-like. $\mathrm{R}$ fork not very narrow basally. $\mathrm{M}$ stem nearly straight or feebly curved; CuA stem at most twice shorter than
$\mathrm{M}+\mathrm{CuA}$ stem. Pterostigma usually present, but poorly developed, slightly darkened, sometimes its base marked with slight bend of RA and its posterior margin with groove.

COMPOSITION. Two subgenera, nominate and Basicella subgen.n.

REMARKS. The publication date for the genus is 1921, not 1920 or 1925 as stated in some papers, because the part 3 of Band 3 of Handlirsch [1920-1921] containing p. 213 with the genus and type species name and illustration was printed in 1921. The detailed description appeared in Handlirsch [1939].

\section{Basicella Shcherbakov, subgen.n.}

TYPE SPECIES: Liadopsylla (Basicella) lautereri Shcherbakov, sp.n.

DIAGNOSIS. Distinct from the other liadopsyllids in the well-developed free $\mathrm{CuA}$ base joining $\mathrm{R}+\mathrm{M}$ at a distance from its apex and separating a small triangular basal cell in the forewing; in one of two described species a nodal line is present (free $\mathrm{CuA}$ base, basal cell and nodal line were not previously reported in Liadopsyllidae).

COMPOSITION. Type species and $L$. (B.) loginovae Shcherbakov, sp.n.

ETYMOLOGY. From Latin basis (foundation, pedestal) and cella (chamber); gender feminine.

\section{Liadopsylla (Basicella) lautereri Shcherbakov, sp.n.} Figs 14-19.

MATERIAL. Holotype forewing PIN 5340/1371 ; paratype forewings PIN 5340/520, 1377 ; paratype (sex unknown) PIN 5340/1498; Khasurty, $10 \mathrm{~km} \mathrm{~S}$ of Tsakir, Zakamensk district, SW Buryatia, Russia; Lower Cretaceous.
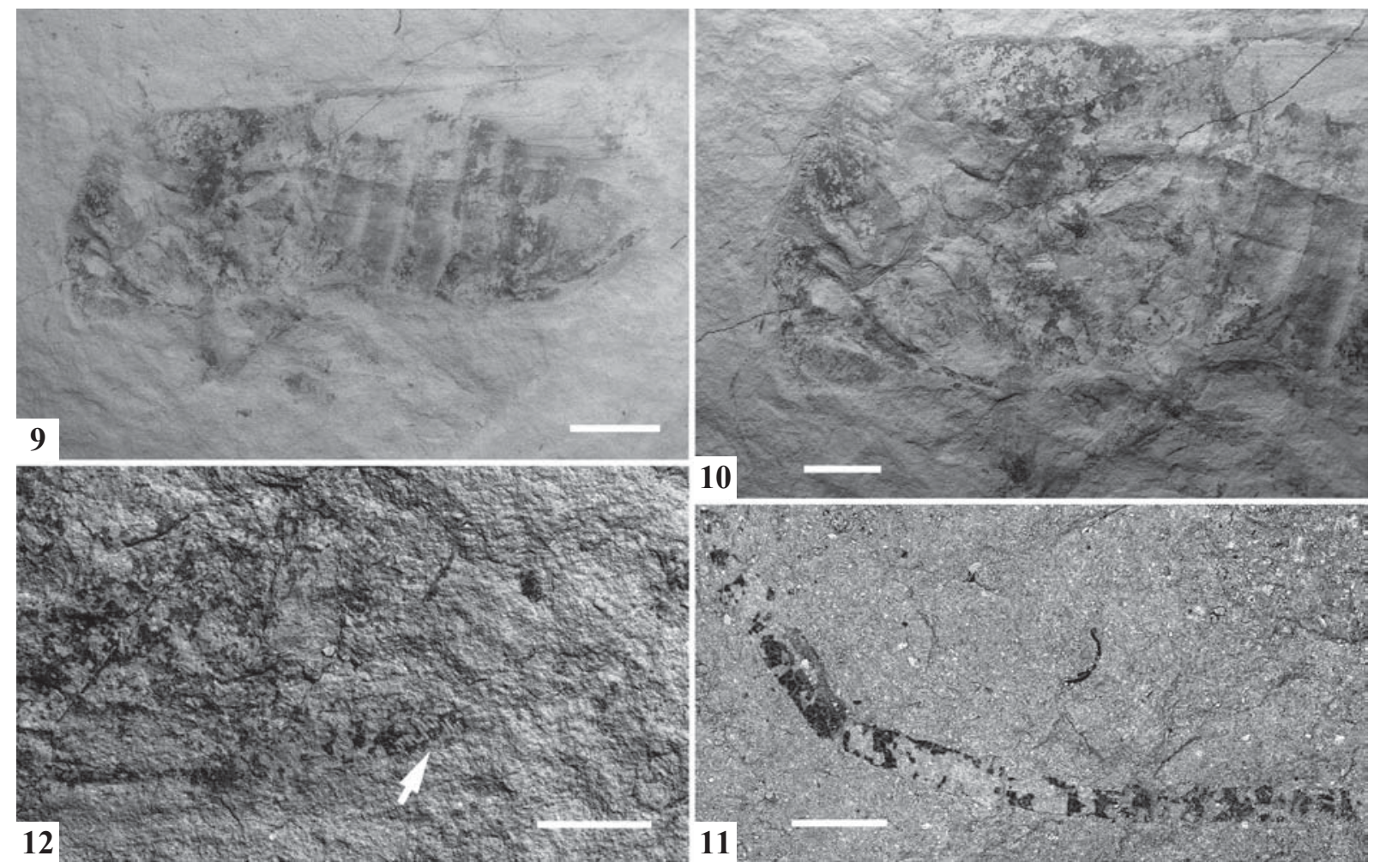

Figs 9-12. Reticycla drosopoulosi gen. et sp.n., paratypes PIN, females, lateral view, SEM (images mirrored); Khasurty, Lower Cretaceous: 9-11 — 5340/521: 9 — body; 10 — head and thorax; 11 — antenna (apex not shown); 12 — 5340/1355, ovipositor (arrow serrate section of inner valvulae). Scale bar: $9-2 \mathrm{~mm}, 10-1 \mathrm{~mm}, 11-0.2 \mathrm{~mm}, 12-0.5 \mathrm{~mm}$.

Рис. 9-12. Reticycla drosopoulosi gen. et sp.n., паратипы ПИН, самки, сбоку, СЭМ (изображения перевёрнуты зеркально); Хасурты, нижний мел: 9-11 - 5340/521:9 — тело; 10 — голова и грудь; 11 - усик (вершина не показана); 12 — 5340/1355, яйцеклад (стрелка - пильчатый участок внутренних створок). Длина масштабной линейки: $9-2$ мм, $10-1$ мм, $11-0,2$ мм, $12-0,5$ мм. 

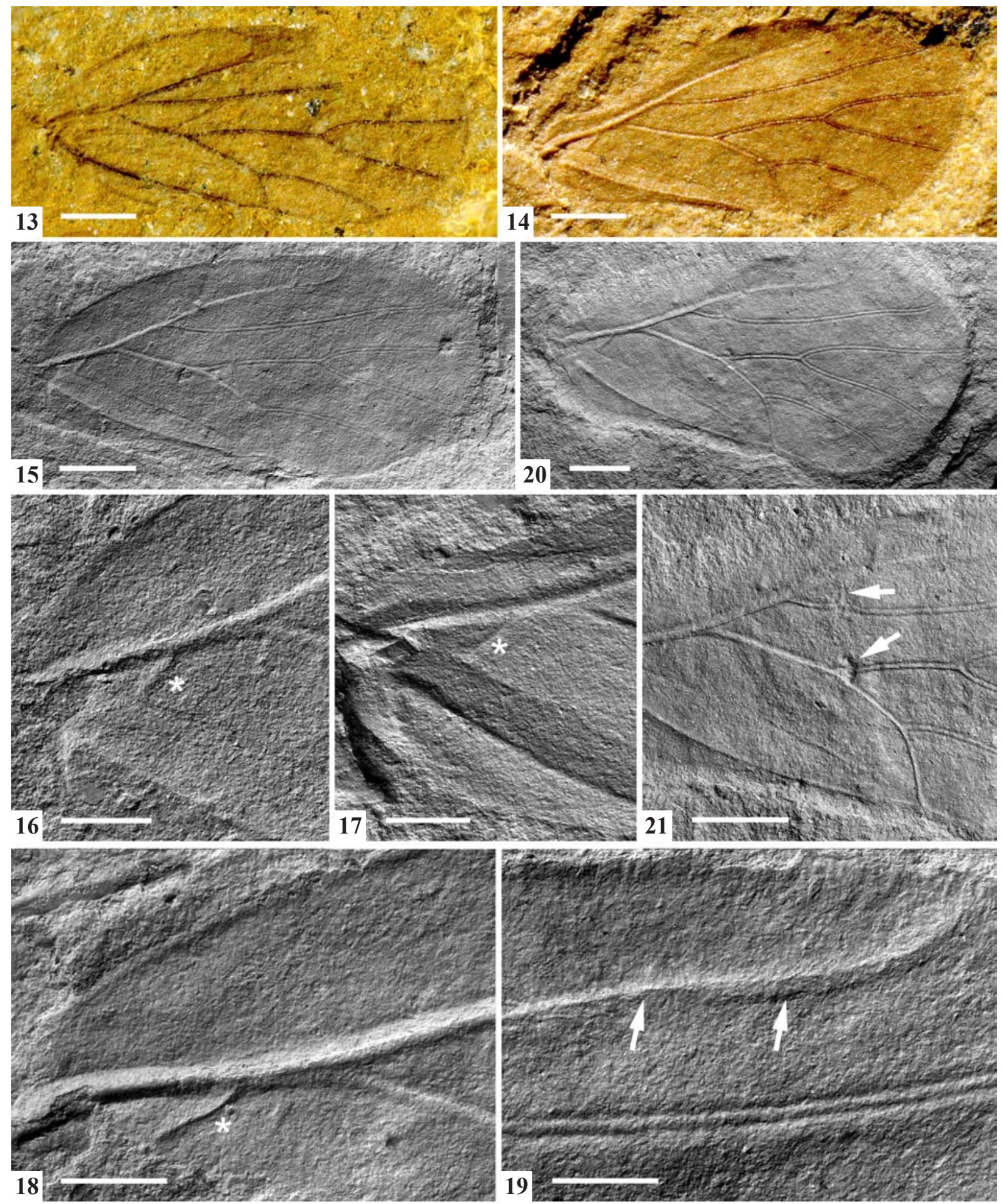

Figs 13-21. Liadopsyllidae, forewings; Khasurty, Lower Cretaceous: 13 - Stigmapsylla klimaszewskii gen. et sp.n., holotype (photograph mirrored); 14-19 — Liadopsylla (Basicella) lautereri subgen. et sp.n.: 14, 17 - paratype PIN 5340/1377 (costal margin tucked under); 1516 - holotype; 18-19 - paratype PIN 5340/520; 20-21 - L. (B.) loginovae sp.n., holotype (costal margin tucked under; images mirrored; arrows - ir crossvein and M break at nodal line); 15-21 — SEM; 16-18 — forewing base (asterisk — free CuA base); 19 - area of pterostigma (arrows — posterior boundary of pterostigma and RA bend at its base). Scale bar: 13-15, 20, $21-0.5 \mathrm{~mm}, 16-19-0.2 \mathrm{~mm}$.

Рис. 13-21. Liadopsyllidae, передние крылья; Хасурты, нижний мел: 13 - Stigmapsylla klimaszewskii gen. et sp.n., голотип (фото перевёрнуто зеркально); 14-19 - Liadopsylla (Basicella) lautereri subgen. et sp.n.: 14, 17 - паратип ПИН 5340/1377 (костальный край подогнут); 15-16 - голотип; 18-19 - паратип ПИН 5340/520; 20-21 - L. (B.) loginovae sp.n., голотип (костальный край подогнут; изображения перевёрнуты зеркально; стрелки — поперечная жилка $i r$ и разрыв М на нодальной линии); $15-21-\mathrm{CЭM;}$ 16-18 - основание переднего крыла (звёздочка — свободное основание СuA); 19 - область птеростигмы (стрелки —задний край птеростигмы и изгиб RA в её основании). Длина масштабной линейки: $13-15,20,21-0,5$ мм, 16-19-0,2 мм. 
DESCRIPTION. Forewing 2.8-3.3 mm long, moderately elongate (2.0-2.1:1), widened up to apex of pterostigma, obliquely rounded apically, tornus inconspicuous. Nodal line absent. Costal margin evenly arched; costal space moderately wide. Pterostigma barely noticeable by darker, raised membrane and wider distal $\mathrm{RA} . \mathrm{R}+\mathrm{M}+\mathrm{CuA}$ dividing before or at $1 / 5, \mathrm{R}$ stem before $1 / 3$, and $\mathrm{M}+\mathrm{CuA}$ before 0.4 wing length. $\mathrm{R}$ fork moderately wide basally, acute with gently curved RA and proximal RP. RA x1.5 shorter than RP, curved forwards before apex; RP slightly sigmoidal distally. $\mathrm{M}+\mathrm{CuA}$ stem $\mathrm{x} 1.5-2.0$ as long as $\mathrm{R}$ stem and slightly longer than $\mathrm{R}+\mathrm{M}(+\mathrm{CuA})$. $\mathrm{M}$ stem somewhat shorter than (or equal to) M2 and x1.6-2.0 as long as $\mathrm{CuA}$ stem, $\mathrm{M}$ fork relatively short and wide $(2.2-2.5: 1)$. CuA1 x2.2-2.3 as long as $\mathrm{CuA}$ stem and $\mathrm{x} 2.7-3.4$ as $\mathrm{CuA} 2$. Clavus narrow, with concave posterior margin; $\mathrm{Pcu}+1 \mathrm{~A}$ distally running along the margin and joining it near clavus apex. Veins dark, especially RP, M and CuA, membrane slightly darkened, more so around apex.
VARIATION. The largest forewing PIN 5340/520 with the base of pterostigma marked with a slight RA bend and its boundary with a groove posterior to RA (Fig. 19), and the M and $\mathrm{CuA}$ veins darker than in other specimens, may represent the female sex or another, closely similar species. In two other paratypes, the $\mathrm{R}$ stem is relatively shorter (about $1 / 2$ of $\mathrm{M}+\mathrm{CuA}$ stem) than in the holotype, and in one of them, M2 is equal to $\mathrm{M}$ stem and $\mathrm{CuA} 2$ short.

ETYMOLOGY. To the memory of a Czech expert in psyllids, Pavel Lauterer (1933-2016).

\section{Liadopsylla (Basicella) loginovae Shcherbakov, sp.n.} Figs 20-21.

MATERIAL. Holotype forewing PIN 5340/2645 \pm ; Khasurty, $10 \mathrm{~km} \mathrm{~S}$ of Tsakir, Zakamensk district, SW Buryatia, Russia; Lower Cretaceous.

DESCRIPTION. Forewing $3.4 \mathrm{~mm}$ long, moderately elongate $(2.0: 1)$, widened up to apex of pterostigma, bluntly rounded apically, tornus well developed. Nodal line present,
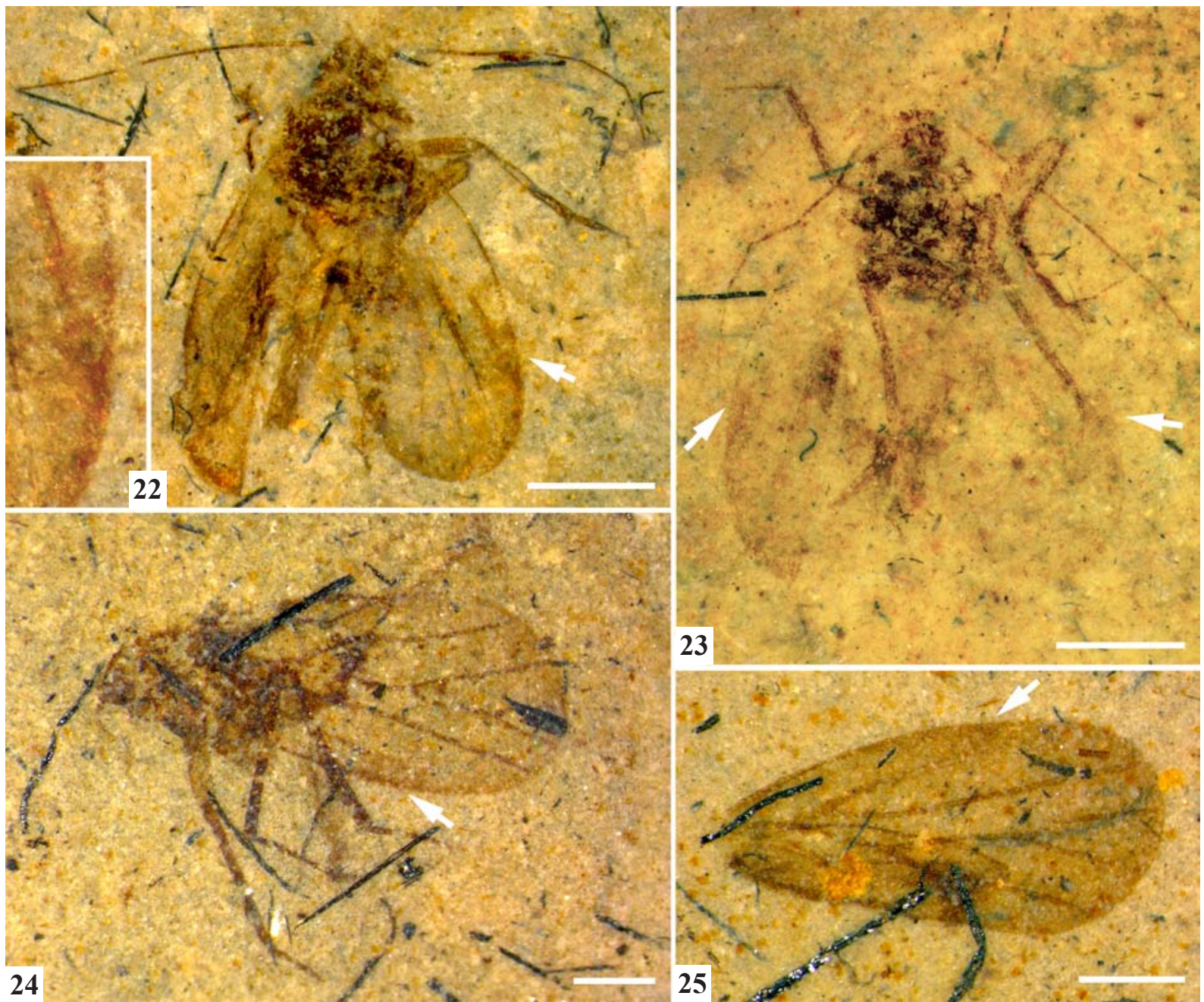

Figs 22-25. Liadopsylla s. str.; Karatau, Middle-Upper Jurassic: 22 - L. turkestanica Becker-Migdisova, 1949, holotype (inset — area of pterostigma); 23 - L. grandis Becker-Migdisova, 1985, paratype PIN 2384/328; 24 - L. asiatica Becker-Migdisova, 1985, holotype (photograph mirrored); 25 - L. brevifurcata Becker-Migdisova, 1985, holotype forewing; arrow — pterostigma. Scale bar: $22-23-1 \mathrm{~mm}$, $24-25-0.5 \mathrm{~mm}$

Figs 22-25. Liadopsylla s. str.; Каратау, средняя-верхняя юра: 22 - L. turkestanica Becker-Migdisova, 1949, голотип (врезка область птеростигмы); 23 - L. grandis Becker-Migdisova, 1985, паратип ПИН 2384/328; 24 - L. asiatica Becker-Migdisova, 1985, голотип (фото перевёрнуто зеркально); 25 - L. brevifurcata Becker-Migdisova, 1985, голотип, переднее крыло; стрелка птеростигма. Длина масштабной линейки: $22-23-1$ мм, 24-25-0,5 мм. 
with ir crossvein and RP bend not far from R fork, and break at base of M stem. Costal margin evenly arched; costal space moderately wide. Base of pterostigma marked with slight RA bend, and its boundary with groove posterior to RA. $\mathrm{R}+\mathrm{M}+\mathrm{CuA}$ dividing at $1 / 5, \mathrm{R}$ stem at $1 / 3$, and $\mathrm{M}+\mathrm{CuA}$ at 0.4 wing length. $\mathrm{R}$ fork moderately wide basally, acute with gently curved RA. RA x1.5 shorter than RP, curved forwards before apex; RP slightly sigmoidal distally. $\mathrm{M}+\mathrm{CuA}$ stem $\mathrm{x} 1.7$ as long as $\mathrm{R}$ stem and subequal to $\mathrm{R}+\mathrm{M}(+\mathrm{CuA})$. M stem half as long as M2 and $\mathrm{x} 1.5$ as $\mathrm{CuA}$ stem, $\mathrm{M}$ fork long and wide (2.2:1). CuA1 nearly thrice longer than $\mathrm{CuA}$ stem or $\mathrm{CuA2}$. Clavus relatively wide, with concave posterior margin; $\mathrm{Pcu}+1 \mathrm{~A}$ distally running along the margin and joining it near clavus apex. Veins and membrane slightly darkened.

REMARKS. Distinct from the type species in the presence of nodal line with a supernumerary ir crossvein, longer $\mathrm{M}$ fork and blunt wing apex.

ETYMOLOGY. To the memory of a Russian expert in psyllids, Marianna M. Loginova.

\section{Cretapsylla Shcherbakov, gen.n.}

TYPE SPECIES: Liadopsylla apedetica Ouvrard, Burckhardt et Azar, 2010

DIAGNOSIS. Distinct from the other genera in the $\mathrm{CuA}$ stem very short, 4-7 times shorter than $\mathrm{M}+\mathrm{CuA}$ stem (at most twice shorter in other genera) and markedly curved $M$ stem (feebly curved or nearly straight in other genera) in the forewing. Similar to Stigmapsylla gen.n. in the very short R stem and basally narrow $\mathrm{R}$ fork, but differs from it in the more curved proximal $\mathrm{RP}$ and $\mathrm{CuA} 1$.

COMPOSITION. C. apedetica (Ouvrard, Burckhardt et Azar, 2010) comb.n., C. hesperia (Ouvrard et Burckhardt, 2010) comb.n.

DISTRIBUTION. Early Cretaceous (Barremian) amber of Lebanon and Late Cretaceous (Turonian) amber of New Jersey.

ETYMOLOGY. From Cretaceous and the generic name Psylla; gender feminine.

Family Malmopsyllidae Becker-Migdisova, 1985

REVISED DIAGNOSIS. Forewing: Pterostigma distinct, dark; costal space widened proximally or distally. $\mathrm{CuA} 2$ rather long, sometimes recurrent. $\mathrm{R}$ bifurcation at $>0.4$, $\mathrm{R}+\mathrm{M}+\mathrm{CuA}$ bifurcation at $>1 / 4$ wing length.

COMPOSITION. Two subfamilies.

Subfamily Malmopsyllinae Becker-Migdisova, 1985, stat.n.

DIAGNOSIS. Forewing: Costal space not widened distally; $\mathrm{M}$ forked; $\mathrm{CuA}$ fork triangular, $\mathrm{CuA} 2$ long, not recurrent. $\mathrm{R}+\mathrm{M}+\mathrm{CuA}$ bifurcation at $1 / 4-1 / 3, \mathrm{R}$ bifurcation at 0.4 $0.5, \mathrm{M}+\mathrm{CuA}$ bifurcation at $0.35-0.5$ wing length.

COMPOSITION. Malmopsylla Becker-Migdisova, 1985, Neopsylloides Becker-Migdisova, 1985, Pauropsylloides
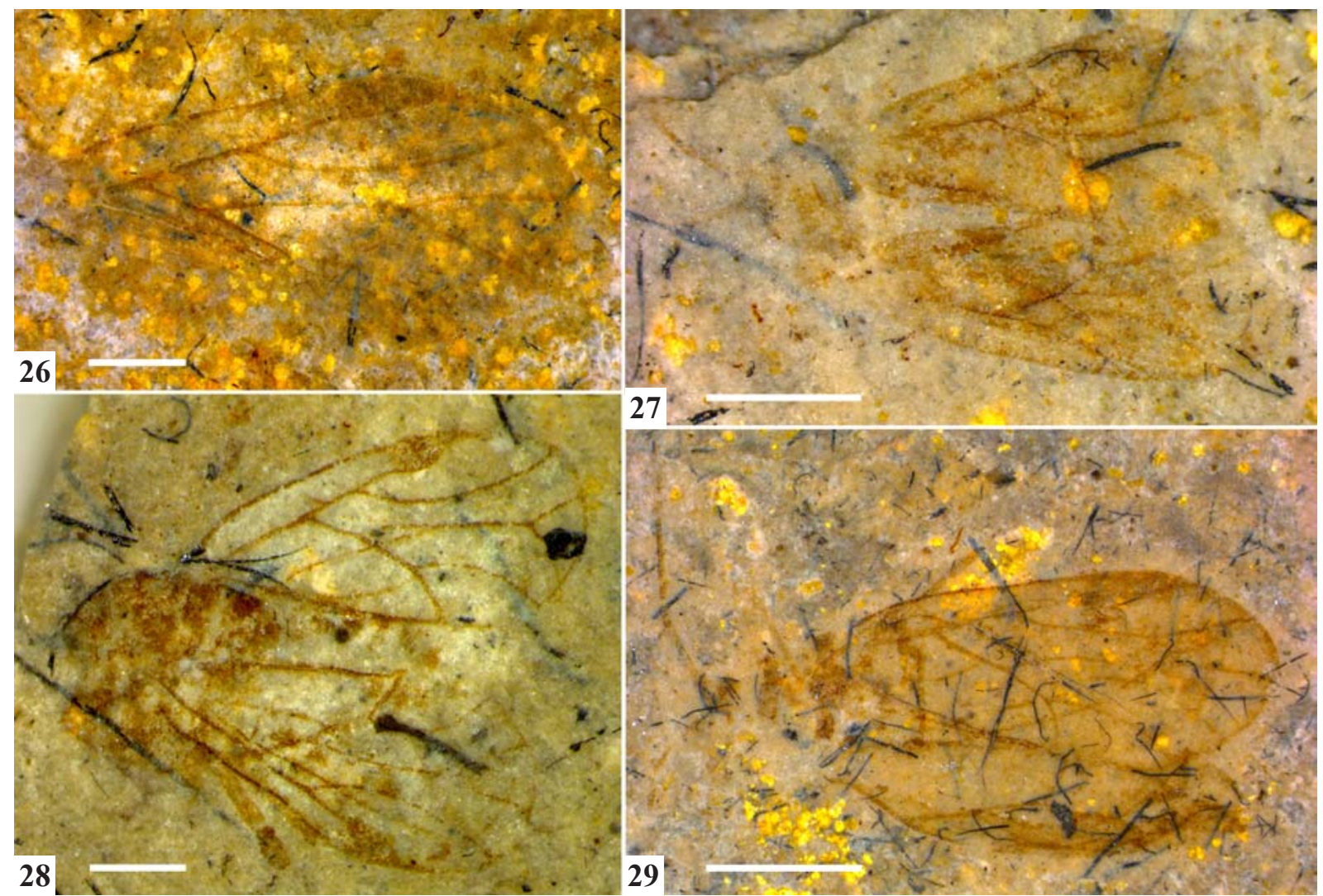

Figs 26-29. Malmopsyllidae, holotypes; Karatau, Middle-Upper Jurassic: 26 - Malmopsylla karatavica Becker-Migdisova, 1985, forewing; 27 - Neopsylloides turutanovae Becker-Migdisova, 1985; 28 - Pauropsylloides jurassica Becker-Migdisova, 1985 (photograph mirrored); 29 - Gracilinervia mastigimatoides Becker-Migdisova, 1985. Scale bar: 26-27 - $1 \mathrm{~mm}, 28-0.5 \mathrm{~mm}, 29-2 \mathrm{~mm}$.

Figs 26-29. Malmopsyllidae, голотипы; Каратау, средняя-верхняя юра: 26 - Malmopsylla karatavica Becker-Migdisova, 1985, переднее крыло; 27 - Neopsylloides turutanovae Becker-Migdisova, 1985; 28 - Pauropsylloides jurassica Becker-Migdisova, 1985 (фото перевёрнуто зеркально); 29 - Gracilinervia mastigimatoides Becker-Migdisova, 1985. Длина масштабной линейки: 26-27 1 мм, $28-0,5$ мм, $29-2$ мм. 
Becker-Migdisova, 1985, Gracilinervia Becker-Migdisova, 1985 (Figs 26-29).

DISTRIBUTION. Middle-Late Jurassic of Kazakhstan.

Subfamily Miralinae Shcherbakov, subfam.n.

TYPE GENUS: Mirala Burckhardt et Poinar, 2020.

DIAGNOSIS. Distinct from the nominate subfamily in the apparently unforked $\mathrm{M}(\mathrm{M}$ and $\mathrm{CuA}$ together with 3 branches), broad subquadrangular $\mathrm{CuA}$ fork with long recurrent $\mathrm{CuA} 2$, costal space widened distally, and further distal shift of main forks $(\mathrm{R}+\mathrm{M}+\mathrm{CuA}$ bifurcation just before, $\mathrm{R}$ and $\mathrm{M}+\mathrm{CuA}$ bifurcations beyond wing midlenth) in the forewing. COMPOSITION. Monotypic.

DISTRIBUTION. Mid-Cretaceous amber of Myanmar.

\section{Discussion}

A new genus of Hylicellidae from Khasurty. The family Hylicellidae was described from the Triassic [Evans, 1956], and its second subfamily Vietocyclinae from the Jurassic and Cretaceous [Shcherbakov, 1988b]. Hylicellidae and Triassic Chiliocyclidae were separated into the superfamily Hylicelloidea, considered ancestral to all three extant superfamilies of Cicadomorpha (Membracoidea, Cercopoidea, and Cicadoidea) [Shcherbakov, 1996]. The family Ligavenidae (Cretaceous) and the superfamily Ligavenoidea [Hamilton, 1992] were synonymized under Hylicellidae and Hylicelloidea, respectively [Shcherbakov, 1996]. The family Archijassidae, once considered a subfamily of Hylicellidae [Shcherbakov, 1992], was moved to Membracoidea [Ansorge, 1996; Shcherbakov, 2012a]. The Triassic family Mesojabloniidae was transferred to Hylicelloidea by Shcherbakov [2011], and the third subfamily Conjucellinae was added to Hylicellidae [Shcherbakov, 2012b]. The family Minlagerrontidae from midCretaceous Burmese amber is tentatively attributed to Hylicelloidea [Chen et al., 2019, 2020].

In addition to two genera and seven species originally assigned to Vietocyclinae by Shcherbakov [1988b], the second species of the genus Vietocycla, V. katyae Fu et Huang, 2019 was recently described from the Aptian of NE China and diagnosed from the type species $V$. peregrina Shcherbakov, 1988 by the number of crossveins and vein terminations [Fu, Huang, 2019]. These characters are quite variable in the type series of $V$. peregrina (holotype and 28 paratypes) [Shcherbakov, $1988 \mathrm{~b}$ ] and are not diagnostic at the species level. However, $V$. katyae seems to be distinct in the absence of dark colour pattern on tegmen, so characteristic of $V$. peregrina from the Aptian of Transbaikalia.

Several other specimens identified as Vietocycla sp. were reported from three other Early Cretaceous localities in Transbaikalia (Shiviya, Tsagan-Nur, Borzya) [Shcherbakov, 1988b]. The record of Vietocycla sp. from the Late Jurassic Glushkovo Formation of Glinyanka, Transbaikalia in the Paleobiology Database [2020] is erroneous — there are no Hemiptera in the material from Glinyanka [Zherikhin, 1990: 8]. Therefore the genus Vietocycla is restricted to the Early Cretaceous.
The genus Reticycla gen.n. from Khasurty with a few strongly oblique postnodal $\mathrm{R}$ branches bridges the gap between the Early Cretaceous genera Vietocycla and Jiphara. Based on several postnodal $\mathrm{R}$ branches arising from dSc, the latter genus was originally ascribed to the family Pereboriidae [Ren, 1995] otherwise recorded only from the Permian, but in fact this genus agrees with Hylicellidae Vietocyclinae in the configuration of basal cell, vein polymerization and other characters.

New taxa of Mesozoic Psylloidea. Liadopsylla geinitzii was described from Early Jurassic of Germany [Handlirsch, 1920-1921, 1939]. Martynov [1927] described another species from the Middle-Late Jurassic of Karatau, Kazakhstan and created the family Liadopsyllidae. Several Jurassic species were added by Becker-Migdisova [1949, 1985] and Ansorge [1996]. The first Early Cretaceous Liadopsylla species was described by Shcherbakov [1988a]. Two Liadopsylla species were discovered in Cretaceous ambers by Ouvrard et al. [2010]. Becker-Migdisova [1985] revised all currently known fossil Psyllomorpha and described the families Malmopsyllidae (monotypic) and Neopsylloididae (3 genera) from the Jurassic of Karatau. The latter family was synonymized under Malmopsyllidae by Klimaszewski and Wojciechowski [1992]. Burckhardt and Poinar [2020] described an extraordinary genus Mirala from mid-Cretaceous Burmese amber, synonymized Malmopsyllidae under Liadopsyllidae and assigned the new genus to the latter family in the broad sense.

Pterostigma is pigmented, clearly delimited from the costal space and marked at base with a distinct bend of RA in many extant psylloids, as well as in Jurassic Malmopsyllidae and Cretaceous Mirala and Stigmapsylla gen.n. Becker-Migdisova [1985: 60] characterized the pterostigma of Liadopsylla s.str. as "wide, open, forming a continuation of the costal space." Seven available Liadopsylla species were re-examined for the development of pterostigma. Slightly darkened pterostig$\mathrm{ma}$ is found in Liadopsylla turkestanica Becker-Migdisova, 1949, L. grandis Becker-Migdisova, 1985, L. asiatica Becker-Migdisova, 1985 and L. brevifurcata Becker-Migdisova, 1985 (Figs 22-25). Such underdeveloped, 'imperfect' pterostigma is marked at base with at most slight bend of RA. In Basicella subgen.n. the pterostigma is likewise present, though little conspicuous: it lacks distinct dark pigmentation, but its limits are often marked with a slight RA bend and then a groove posterior to RA (Figs 19-20).

The free CuA base is clearly visible in the forewings of Basicella subgen.n. finely preserved in the Cretaceous Khasurty fossil beds (Figs 16-18, 20). Such a $\mathrm{CuA}$ base was not found in the well-preserved isolated forewing of L. mongolica Shcherbakov, 1988 from the Aptian of Bon Tsagaan, as well as in six species of Liadopsylla described from the Jurassic of Karatau, in these latter perhaps because the relief is not preserved and most specimens are complete insects with wing bases superimposed on the body. The free $\mathrm{CuA}$ base is an important character: it is usually present in Protopsyllidiidae and more primitive groups and has not 
been previously reported in Mesozoic Psylloidea. This character is of generic value, but it is the only known difference between Liadopsylla s. str. and Basicella, which cannot be checked in many fossils, so for practical purposes we rank the latter taxon as a subgenus. The free CuA base in Basicella can be a reversal rather than primitive character, i.e. restored, and not inherited directly from protopsyllidiid ancestors. Such a $\mathrm{CuA}$ base may be overlooked or not visible in many fossils, so special attention should be paid to this character in liadopsyllids.

Nodal line developed in some extant and Cenozoic Psylloidea [Heslop-Harrison, 1951; Ouvrard et al., 2013] was not previously reported in Liadopsyllidae. In Liadopsylla (Basicella) loginovae sp.n. (Figs 20-21), a nodal line is present, and in contrast to the condition found in recent psyllids (e.g. [Malenovský et al., 2012]), it crosses not R bifurcation but RP slightly distad of its base, the point marked with a slight bend of RP and a supernumerary ir crossvein.

Two species of Liadopsyllidae known from Cretaceous ambers [Ouvrard et al., 2010] differ markedly from all others in the very short CuA stem and curved $\mathrm{M}$ stem, so they are separated into Cretapsylla gen.n.

Burckhardt and Poinar (2020) concluded that the family Malmopsyllidae is morphologically heterogeneous and polyphyletic, and synonymized it under Liadopsyllidae. However, all four genera assigned to Malmopsyllidae (Figs 26-29) differ from Liadopsyllidae s. str. at least in the more distal position of the R bifurcation (at $>0.4$ wing length, ) and $\mathrm{R}+\mathrm{M}+\mathrm{CuA}$ bifurcation (at $>1 / 4$ wing length), compared to at $<1 / 3$ and $<1 / 5$ wing length, respectively, in Liadopsyllidae. Such a distal postion of these bifurcations is characteristic of many extant Psylloidea, therefore Malmopsyllidae likely represent a group more derived than Liadopsyllidae, and synonymization of these two families is not justified. The Cretaceous genus Mirala agrees with malmopsyllids in the even more distal position of these bifurcations, but differs from them (as well as from all other Mesozoic Psyllomorpha) in the apparently unforked $\mathrm{M}$ and long recurrent $\mathrm{CuA} 2$, so it can be placed in Malmopsyllidae as a separate subfamily.

Psyllomorpha, so common in the Jurassic, were previously known from the Cretaceous for a few finds, some of which are still not described. Liadopsyllidae from Khasurty reveal unexpected taxonomic diversity and show some morphological characters formerly unknown in Mesozoic Psylloidea. In the Cretaceous, psyllomorphs were perhaps more locally distributed then in the Jurassic, and Khasurty likely belonged to one of their refugia. Some psyllomorph taxa from Khasurty may represent Jurassic relicts in the Early Cretaceous fauna.

The insects and other fossils of Khasurty. The fossil assemblage of this locality is rich and peculiar (numerical data are based mainly on specimen counts of the 2004 expedition headed by the author).

Aquatic insects are more numerically abundant than terrestrial. The commonest insect group is phantom midges (Chaoboridae) represented by innumerable pu- pae and numerous adults and larvae. Only the wellpreserved chaoborid specimens were collected, and most others discarded (the same was true about other super-plentiful groups such as aphids and tipuloid craneflies). Much less abundant are other Diptera with aquatic larvae (Chironomidae, Simuliidae, Ptychopteridae, some Limoniidae s.1., some Empidoidea), Ephemeroptera (mainly nymphs), Plecoptera (mostly adults), larvae of the large beetle Coptoclava longipoda Ping, 1928 (Coptoclavidae; adults are exceptionally rare); Trichoptera (adults and rare larval cases, larvae and swimming pupae), and scorpionflies Nannochoristidae (adults). The finds of small water beetles (Hydrophilidae, Jurodidae, etc.), damselfly nymphs (Zygoptera), and adult water boatmen (Corixidae) are rare. Some of the minor aquatic groups likely inhabited small rivers and brooks rather than the Khasurty paleolake. Other aquatic arthropods are water fleas (Prochydoridae) [Kotov, 2009] and clam shrimps (Conchostraca). Fish remains are exceptionally rare.

The terrestrial insect assemblage is dominated by super-plentiful winged aphids (Aphidomorpha). Only the better-preserved aphid specimens taken by collectors make up more than $30 \%$ of total terrestrial insects. It is higher share than in any other Mesozoic locality known to the author. Nematocerous Diptera are very diverse and abundant: common Trichoceridae and Limoniidae s.1, various Sciaroidea, uncommon Anisopodidae, Axymyiidae, and Perissommatidae. Hymenoptera are on the third place among terrestrial groups, or maybe on the second, if we consider that many groups of Diptera have aquatic larvae. Hymenopterans are more abundant than in other Mesozoic assemblages (more than $8 \%$ of total insects), very diverse (more than 25 families, half of the number of families of other terrestrial insects), and dominated by Xyelidae (about $30 \%$ of total hymenopterans). The less numerous are terrestrial bugs and beetles, brachycerous Diptera, and scorpionflies. Not rare are Neuroptera, small moths (Lepidoptera) and Lophioneuridae (ancestral to Thysanoptera). The rarest groups are Raphidioptera, Orthoptera, Grylloblattodea, and true Thysanoptera. Notable is the absence of Blattodea.

The non-aphid Homoptera are moderately diverse and comparatively rare (about twenty times less abundant than aphids). Coleorrhyncha are represented by numerous Karabasiidae and rare Progonocimicidae, and Auchenorrhyncha Cicadomorpha - with several Palaeontinidae and Hylicellidae and a few Procercopidae (Cercopoidea) and Archijassidae (Membracoidea). Notable is the extreme rarity of Fulgoroidea and the absence of Tettigarctidae (Cicadoidea). In contrast to all other known Cretaceous localities, jumping plant lice (Psyllomorpha) are common and diverse; both Protopsyllidiidae and Liadopsyllidae are found.

Besides insects, several small spiders and harvestmen were found, as well as small feathers of birds or dinosaurs. Bryophytes are quite common and represented by 4 genera and 6 species of mosses, all floating or growing on banks [Ignatov, Shcherbakov, 2011], and one species 
of hepatics [Mamontov, Ignatov, 2019]. The finds of vascular plants are little diverse and fragmentary: fern pinnules, conifer needles and seeds (Pityospermum), hairy achenes of proangiosperms (Baisia), etc.

On the age of the Khasurty entomofauna. The Khasurty fossil beds belong to a very small, isolated block of the Mesozoic deposits surrounded by Paleozoic rocks [Gordienko et al., 2018]. These fossil beds were attributed to the Gusinoe Ozero (Gusinoozerskaya) Group, formerly dated as Middle Jurassic-Early Cretaceous, now as Early Cretaceous [Skoblo et al., 2001]. Several features of the Khasurty insect assemblage confirm the Early Cretaceous age of the strata.

1. Such a high numerical abundance of aphids is recorded only in several Early Cretaceous entomofaunas of Transbaikalia (Baissa, Turga) and Mongolia (Hotont, Hutel-Hara, Hutuliyn), all with aphids making up 16$24 \%$ (or even more) of terrestrial insects [Wegierek, 1990]. In many other Early Cretaceous insect faunas of Transbaikalia and Mongolia, the aphids make up from $\sim 1$ to $7 \%$, and in some Jurassic faunas of Asia much less than $1 \%$ of terrestrial insects (ibid.); of course, in still many other Cretaceous insect faunas aphids are absent altogether (we have no numerical data on Chinese localities). Such localities as Hotont, Hutel-Hara, and Hutuliyn were formerly dated as belonging to the Late Jurassic-Early Cretaceous transitional interval, but a detailed analysis demonstrated that they are earliest Cretaceous (Turga Horizon, Berriasian-Valanginian) [Dmitriev, 2020].

Modern aphids are much more diverse in the northern temperate zone than in the tropics or southern temperate zone [Heie, 1994]. Such an unusual pattern of the geographical distribution, explained by the low thermal tolerance of bacterial symbiont of aphids, has existed since the Early Cretaceous [Perkovsky, Wegierek, 2017]. The five abovementioned aphid-rich localities and Khasurty are all confined to a comparatively small area (ca. 1000 x $1000 \mathrm{~km} ; 45.8-56.0^{\circ}$ paleoN, 101.4-111.4 ${ }^{\circ}$ paleoE) [Paleobiology Database, 2020] of the Cretaceous northern warm temperate zone close to the NE limit of boreotropical zone [Boucot et al., 2013]. In the latest Jurassic--earliest Cretaceous, this region underwent intense collisional orogeny west of the closing Mongol-Okhotsk Ocean and a cooling event [Yang et al., 2015]. Probably, the humid mountainous variant of temperate climate was characteristic of Khasurty in the Early Cretaceous, which favoured the high abundance and diversity of aphids.

2. The aquatic beetle Coptoclava longipoda (Coptoclavidae) common in the Khasurty assemblage is an index insect fossil confined to the Early Cretaceous of East Asia (Ponomarenko, 1961; Prokin et al., 2013; Zhao et. al., 2018). However, the giant mayfly Ephemeropsis Eichwald, 1864 usually associated with C. longipoda in widespread faunas of the Ephemeropsis-Coptoclava type [Zherikhin, 1978; Zherikhin et al., 1999; Mostovski et al., 2000] is replaced in the Khasurty assemblage with smaller mayflies of several genera, including a related genus Baikalogenites Sinitshenkova, 2017 [Sinitshenkova, 2017].
3. The Khasurty fauna includes several families and genera recorded elsewhere only from the Early Cretaceous: hymenopterans Praeichneumonidae [Kopylov, 2012], Archaeocynipidae [Kopylov, 2014], Trematothorax Rasnitsyn, 1988 [Kopylov, Rasnitsyn, 2017], Amplicella Kopylov, 2010 and Khasurtella Kopylov, 2011 [Kopylov, 2011]; dipterans Mangas Kovalev, 1986 [Greenwalt, Blagoderov, 2019], Zhiganka Lukashevich, 1995 [Lukashevich, 2019], Kaluginamyia Lukashevich, Pepinelli et Currie, 2019 [Lukashevich et al., 2020], Collessomma Lukashevich et Blagoderov, 2020 [Lukashevich, Blagoderov, 2020], etc.

4. There are similarities at the species level between Khasurty and undoubtedly Cretaceous faunas. Amplicella shcherbakovi Kopylov, 2011 is recorded from Khasurty and Dabeigou Formation, Hauterivian of China [Kopylov, Zhang, 2015]. The Khasurty species of Ghilarella Rasnitsyn, 1988 is indistinguishable from $G$. mercurialis Rasnitsyn, 1988 from Bon-Tsagan, Aptian of Mongolia [Kopylov, Rasnitsyn, 2017]. Some other Khasurty species are closely similar to those from the Early Cretaceous, e.g. Mesypochrysa cannabina Khramov, 2018 to $M$. cf. chrysopoides Ponomarenko, 1992 from the Yixian Formation, Aptian of China [Khramov, 2018].

5. The Khasurty assemblage contains several insect families unknown from the pre-Cretaceous strata, such as Bolitophilidae, Braconidae, Proctotrupidae, and several others.

Therefore, there is little doubt about the Early Cretaceous age of the Khasurty entomofauna, in accordance with the opinion of regional stratigraphers.

However, there are some other features, which relate the Khasurty entomofauna to the Jurassic ones.

6. Comparative abundance of Lophioneuridae, Protopsyllidiidae, Liadopsyllidae, Karabasiidae, Megalyridae, Nemonychidae Brenthorhininae and several other taxa, which are usually rare in the Cretaceous.

7. Presence of some taxa unknown elsewhere after the Jurassic: beetles Jurodidae [Yan, Strelnikova, 2019] and Gracilicupes Tan, Ren et Shih, 2006 [Strelnikova, 2019] and stoneflies Dimoula Sinitshenkova, 2005 and Rasnitsyrina Sinitshenkova, 2011 [Sinitshenkova, 2011].

8. The species in common between Khasurty and Late Jurassic faunas - Jurodes minor Ponomarenko, 1990 (Coleoptera) [Yan, Strelnikova, 2019] known also from the Late Jurassic Glushkovo Formation of eastern Transbaikalia.

Concluding from the features 1-5 that Khasurty is of Early Cretaceous age, we could explain the features 68 through persistence of the Jurassic relicts in a favourable climate, perhaps not unlike the humid temperate climate of present-day extratropical rainforests of the Southern Hemisphere.

The Early Cretaceous Homoptera assemblage of Khasurty has a relict appearance: it is enriched with the families Protopsyllidiidae, Liadopsyllidae and Karabasiidae, which are widespread in the Jurassic and rare in the Cretaceous [Shcherbakov, 1988b; Popov, Shcherbakov, 1996]. Its fourth major component is an 
endemic genus of the Jurassic-Early Cretaceous subfamily Vietocyclinae (Hylicellidae), intermediate between two other Early Cretaceous genera. Liadopsyllids from Khasurty belonging to an endemic genus and an endemic subgenus have derived traits as well as seemingly primitive features, and the genus shows some similarity to another Cretaceous genus.

On the paleoenvironment of Khasurty. Cockroaches, termites, earwigs, orthopterans, cicadas, and planthoppers are rather thermophilic. These groups are present and sometimes common in many Late Jurassic and Early Cretaceous faunas of Asia, but absent or (orthopterans, planthoppers) very rare in the Khasurty fauna. This fact, as well as the extraordinary abundance of aphids and relative abundance of xyelid sawflies, can be explained by the climate near Khasurty paleolake cooler and wetter than reconstructed for many other Late Mesozoic localities of Transbaikalia and Mongolia, probably due to some local geographic features.

High abundance of aphids (primitive groups of which live on trees and shrubs) and hymenopterans (including the groups with wood-boring larvae and their parasites), as well as finds of conifer seeds and needles, indicate the presence of various woody plants around the Khasurty paleolake. Living Coleorrhyncha feed on mosses, and the Mesozoic ones probably also fed on them, so plenty of mosses is a likely cause of the abundance of Karabasiidae in the Khasurty fauna. The low abundance and diversity of Auchenorrhyncha feeding on various vascular plants indicate that some plant groups were underrepresented or absent in the Khasurty paleoflora.

We can conclude that the Khasurty fossils were preserved in the deposits of a fish-deficient intermontane paleolake in a forested region with rather cool, humid temperate climate.

Acknowledgements. I am grateful to Olga Minina (Geological Institute, Siberian Branch, RAS) for information on the locality, all the colleagues from the Arthropoda Lab, PIN and Andrei Legalov (Institute of Systematics and Ecology of Animals, Siberian Branch, RAS) for identifying the specimens, and Roman Rakitov (PIN) for valuable discussion. The study was supported by the RFBR project 18-04-00322.

\section{References}

Ansorge J. 1996. Insekten aus dem oberen Lias von Grimmen (Vorpommern, Norddeutschland) // N. Paläont. Abh. Vol.2. P.1-132.

Becker-Migdisova E.E. 1949. [Mesozoic Homoptera of Central Asia] // Trudy Paleontol. Inst. Akad. Nauk SSSR. Vol.22. P.168 [in Russian].

Becker-Migdisova E.E. 1985. [Fossil psyllomorphous insects] // Trudy Paleontol. Inst. Akad. Nauk SSSR. Vol.206. P.1-94 [in Russian].

Blagoderov V.A., Lukashevich E.D. 2013. New Axymyiidae (Insecta: Diptera) from the Mesozoic of East Siberia // Pol. J. Entomol. Vol.82. P.257-271.

Boucot A.J., Xu C., Scotese C.R., Morley R.J. 2013. Phanerozoic paleoclimate: an atlas of lithologic indicators of climate // SEPM Concepts in Sedimentology and Paleontology. No.11: Map Folio. Tulsa, Oklahoma: Society for Sedimentary Geology. 30 pp.
Burckhardt D., Poinar G. 2020. The first jumping plant-louse from mid-Cretaceous Burmese amber and its impact on the classification of Mesozoic psylloids (Hemiptera: Sternorrhyncha: Psylloidea s.1.) // Cretac. Res. Vol.106. 104240.

Chen J., Szwedo J., Wang B., Zheng Y., Jiang H., Jiang T., Wang X., Zhang H. 2019. A new bizarre cicadomorph family in midCretaceous Burmese amber (Hemiptera, Clypeata) // Cretac. Res. Vol.97. P.1-15.

Chen J., Wang B., Zhang H., Jiang H., Jiang T., Zheng Y., Wang X. 2020. New discovery of Minlagerrontidae in mid-Cretaceous Burmese amber (Hemiptera, Cicadomorpha, Clypeata) // Cretac. Res. Vol.106. 104204.

Dmitriev V.Yu. 2020. [Early Cretaceous insect assemblages of Central Asia] http://palaeoentomolog.ru/bibl/entomocomplex.html [in Russian].

Drosopoulos S., Maryańska-Nadachowska A., Kuznetsova V.G. 2010. The Mediterranean: Area of origin of polymorphism and speciation in the spittlebug Philaenus (Hemiptera, Aphrophoridae) // Zoosyst. Evol. Vol.86. P.125-128.

Evans J.W. 1956. Palaeozoic and Mesozoic Hemiptera (Insecta) // Aust. J. Zool. Vol.4. P.165-258.

Fu Y., Huang D. 2019. New Early Cretaceous hylicellids (Insecta: Hemiptera: Cicadomorpha) from Southwest Beijing, China // Palaeoentomol. Vol.2. P.17-21.

Gordienko I.V., Gorokhovsky D.V., Smirnova O.K., Lantseva V.S., Badmatsyrenova R.A., Orsoev D.A. 2018. Dzhida ore district: geology, structural and metallogenic regionalization, genetic types of ore deposits, geodynamic conditions of their formation, forecast, and outlook for development // Geol. Ore Deposits. Vol.60. P.1-32.

Gratshev V.G., Legalov A.A. 2014. The Mesozoic stage of evolution of the family Nemonychidae (Coleoptera, Curculionoidea) // Paleontol. J. Vol.48. P.851-944.

Greenwalt D.E., Blagoderov V.A. 2019. Review of the fossil record of Bolitophilidae, with description of new taxa and discussion of position of Mangas Kovalev (Diptera: Sciaroidea) // Zootaxa. Vol.4567. P.546-560.

Handlirsch A. 1920-1921. Palaeontologie // C. Schröder (Hrsg.). Handbuch der Entomologie. Jena: G. Fischer. Bd.3. S.117-306.

Handlirsch A. 1939. Neue Untersuchungen über die fossilen Insekten mit Ergänzungen und Nachträgen sowie Ausblicken auf phylogenetische, palaeogeographische und allgemein biologische Probleme. II. Teil // Ann. naturhist. Mus. Wien. Bd.49. S.1-240.

Hamilton K.G.A. 1992. Lower Cretaceous Homoptera from the Koonwarra Fossil Bed in Australia, with a new superfamily and synopsis of Mesozoic Homoptera // Ann. Entomol. Soc. Am. Vol.85. P.423-430.

Heie O.E. 1994. Why are there so few aphid species in the temperate areas of the southern hemisphere? // Eur. J. Entomol. Vol.91. P.127-133.

Heslop-Harrison G. 1951. Subfamily separation in the Homopterous Psyllidæ. - II // Ann. Mag. Nat. Hist. Ser.12. Vol.4. No.37. P.135.

Ignatov M.S., Shcherbakov D.E. 2011. Lower Cretaceous mosses from Khasurty (Transbaikalia) // Arctoa. Vol.20. P.19-42.

Khramov A.V. 2018. A new assemblage of Early Cretaceous green lacewings (Chrysopidae: Neuroptera) from Transbaikalia//Earth Environ. Sci. Trans. R. Soc. Edinb. Vol.107. P.195-202.

Klimaszewski S.M., Wojciechowski W. 1992. Relationships of recent and fossil groups of Sternorrhyncha as indicated by the structure of their fore wings // Prace Nauk. Uniw. Sląsk. Katowice. No.1318. P.1-50.

Kopylov D.S. 2011 Ichneumon wasps of the Khasurty locality in Transbaikalia (Insecta, Hymenoptera, Ichneumonidae) // Paleontol. J. Vol.45. P.406-413.

Kopylov D.S. 2012. New species of Praeichneumonidae (Hymenoptera, Ichneumonoidea) from the lower Cretaceous of Transbaikalia // Paleontol. J. Vol.46. P.66-72.

Kopylov D.S. 2014. New archaeocynipids (Hymenoptera, Cynipoidea, Archaeocynipidae) from the Lower Cretaceous of Transbaikalia // Paleontol. J. Vol.48. P.58-64.

Kopylov D.S., Rasnitsyn A.P. 2014. New Trematothoracinae (Hymenoptera: Sepulcidae) from the Lower Cretaceous of Trans- 
baikalia // Proc. Russ. Entomol. Soc. Vol.85. No.1. P.199-206.

Kopylov D.S., Rasnitsyn, A.P. 2017. New sepulcids (Hymenoptera: Sepulcidae) from the Lower Cretaceous of Asia: II. Ghilarellinae and Trematothoracinae // Paleontol. J. Vol.51. P.291-303.

Kopylov D.S., Zhang H. 2015. New ichneumonids (Insecta: Hymenoptera: Ichneumonidae) from the Lower Cretaceous of north China // Cretac. Res. Vol.52. P.591-604.

Kotov A.A. 2009. A revision of the extinct Mesozoic family Prochydorusidae Smirnov, 1992 (Crustacea: Cladocera) with a discussion of its phylogenetic position // Zool. J. Linn. Soc. Vol.155. P.253-265.

Legalov A.A. 2010. Checklist of Mesozoic Curculionoidea (Coleoptera) with description of new taxa // Balt. J. Coleopterol. Vol.10. P.71-101.

Lukashevich E.D. 2019. Review of the fossil record of Bittacomorphinae (Diptera: Ptychopteridae) // Zootaxa. Vol.4661. P.566578.

Lukashevich E.D., Blagoderov V.A. 2020. Review of Mesozoic Perissommatidae (Insecta: Diptera) // Zootaxa. Vol.4718. P.481496.

Lukashevich E.D., Pepinelli M., Currie D.C. 2020. A new family and genus of Mesozoic Simulioidea (Insecta: Diptera) // J. Syst. Palaeontol. Vol.18. P.213-231.

Malenovský I., Lauterer P., Labina E., Burckhardt D. 2012. Jumping plant-lice (Hemiptera: Psylloidea) of Afghanistan // Acta Ent. Mus. Nat. Pragae. Vol.52. P.1-22.

Mamontov Y.S., Ignatov M.S. 2019. How to rely on the unreliable: Examples from Mesozoic bryophytes of Transbaikalia // J. Syst. Evol. Vol.57. P.339-360.

Martynov A.V. 1927. Jurassic fossil insects from Turkestan. 6 Homoptera and Psocoptera // Bull. Acad. Sci. URSS. 1926. Ser.6. Vol.20. No.13-14. P.1349-1366.

Mostovski M.B., Jarzembowski E.A., Coram R.A., Ansorge J. 2000. Curious snipe-flies (Diptera: Rhagionidae) from the Purbeck of Dorset, the Wealden of the Weald and the Lower Cretaceous of Spain and Transbaikalia // Proc. Geol. Assoc. Vol.111. P.153-160.

Ouvrard D., Burckhardt D., Azar D., Grimaldi D. 2010. Nonjumping plantlice in Cretaceous amber (Hemiptera: Sternorrhyncha: Psylloidea) // Syst. Entomol. Vol.35. P.172-180.

Ouvrard D., Burckhardt D., Greenwalt D. 2013. The oldest jumping plant-louse (Hemiptera: Sternorrhyncha) with comments on the classification and nomenclature of the Palaeogene Psylloidea // Acta Mus. Moraviae. Sci. biol. Brno. Vol.98. No.2. P.21-33.

Paleobiology Database 2020. http://fossilworks.org

Perkovsky E., Wegierek P. 2018. Aphid-Buchnera-Ant symbiosis, or why are aphids rare in the tropics and very rare further south? // Earth Environ. Sci. Trans. R. Soc. Edinb. Vol.107. P.297-310.

Ponomarenko A.G. 1961. About the systematic position of Coptoclava longipoda Ping (Insecta, Coleoptera) // Paleontol. Zh. No.3. P.67-72 [in Russian].

Ponomarenko A.G., Sukatsheva I.D., Vasilenko D.V. 2009. Some characteristics of the Trichoptera distribution in the Mesozoic of Eurasia (Insecta: Trichoptera) // Paleontol. J. Vol.43. P.282-295.

Popov Yu.A., Shcherbakov D. E. 1996. Origin and evolution of the Coleorrhyncha as shown by the fossil record // C.W. Schaefer (Ed.). Studies on Hemipteran Phylogeny. Lanham (Maryland): Entomological Society of America. P. 9-30.

Prokin A.A., Makarov K.V., Ponomarenko A.G., Bashkuev A.S. 2013. New beetle larvae (Coleoptera: Coptoclavidae, Caraboidea, Polyphaga) from the Upper Triassic of Germany // Russ. Entomol. J. Vol.22. No.4. P.259-274.

Ren D. 1995. Insecta // D. Ren et al. (Eds). Faunae and Stratigraphy of Jurassic-Cretaceous in Beijing and the Adjacent Areas. Beijing: Geological Publishing House. P.47-121.

Shcherbakov D.E. 1988a. [New Mesozoic Homoptera] // A.Yu. Rozanov (ed.). [New Species of Fossil Invertebrates of Mongolia]. Trudy Sovmest. Sov.-Mongol. Paleontol. Exped. Vol.33. P.60-63 [in Russian].

Shcherbakov D.E. 1988b. New cicadas (Cicadina) from the Late Mesozoic of Transbaikalia // Paleontol. J. Vol.22. No.4. P.52-63.
Shcherbakov D.E. 1992. The earliest leafhoppers (Hemiptera: Karajassidae n. fam.) from the Jurassic of Karatau // N. Jahrb. Geol. Paläontol. Monatsh. No.1. P.39-51.

Shcherbakov D.E. 1996. Origin and evolution of the Auchenorrhyncha as shown by the fossil record // C.W. Schaefer (Ed.). Studies on Hemipteran Phylogeny. Lanham (Maryland): Entomological Society of America. P.31-45.

Shcherbakov D.E. 2011. New and little-known families of Hemiptera Cicadomorpha from the Triassic of Central Asia - early analogs of treehoppers and planthoppers // Zootaxa. Vol.2836. P.1-26.

Shcherbakov D.E. 2012a. More on Mesozoic Membracoidea // Russ. Entomol. J. Vol.21. No.1. P.15-22.

Shcherbakov D.E. 2012b. A new subfamily of Mesozoic Hylicellidae (Homoptera Cicadomorpha) // Russ. Entomol. J. Vol.21. No.4. P.441-444

Sinitshenkova N.D. 2011. New stoneflies (Insecta: Perlida= Plecoptera) from the Late Mesozoic locality Khasurty, Transbaikalia // Paleontol. J. Vol.45. P.552-558.

Sinitshenkova N.D. 2017. New mayflies (Insecta: Ephemerida= Ephemeroptera) from the Upper Mesozoic locality of Khasurty, Western Transbaikalia // Paleontol. J. Vol.51. P.280-287.

Skoblo V.M., Lyamina N.A., Rudnev A.F., Luzina I.V. 2001. [Continental Upper Mesozoic of Cisbaikalia and Transbaikalia: Stratigraphy, Depositional Conditions, and Correlation]. Novosibirsk: Izdatel'stvo Sibirskogo otdeleniya Rossiyskoi Akademii nauk. 332 p. [in Russian].

Strelnikova O.D. 2019. New cupedids (Insecta: Coleoptera, Cupedidae) from the Lower Cretaceous of Buryatia // Paleontol. J. Vol.53. P.292-299.

Sukatsheva I.D., Vasilenko D.V. 2019. New caddisflies of the family Dysoneuridae (Insecta: Trichoptera) and larval cases (incertae familiae) from the Lower Cretaceous of Transbaikalia // Paleontol. J. Vol.53. P.499-505.

Tishechkin D.Y. 2012. Taxonomy and biology of leafhoppers of the genus Macropsis (Homoptera, Cicadellidae, Macropsinae) living on Berberis spp. (Berberidaceae) // Entomol. Rev. Vol.92. P.977-987.

Wegierek P. 1990. [The Early Cretaceous stage of evolution of aphids] PhD thesis. Moscow: Paleontological Institute Ac. Sci. USSR. 140 p. [in Russian].

Yan E.V., Strelnikova O.D. 2019. [New finds of Jurodidae (Insecta; Coleoptera) from the Lower Cretaceous locality Khasurty confirm the family placement in Archostemata] // Sovremennaya paleontologiya: klassicheskie i noveishie metody. XVI vserossiyskaya nauchnaya shkola molodykh uchenykh-paleontologov 14-16 oktyabrya 2019 g. Abstracts. Moscow: Borissiak Paleontological Institute of the Russian Academy of Sciences. P.31-32 [in Russian].

Yang Y.T., Guo Z.X., Song C.C., Li X.B., He S. 2015. A short-lived but significant Mongol-Okhotsk collisional orogeny in latest Jurassic-earliest Cretaceous // Gondwana Res. Vol.28. P.10961116.

Zhao X., Zhao X., Jarzembowski E.A., Chen L., Wang B. 2018. First record of adult Coptoclava longipoda Ping (Coleoptera: Coptoclavidae) from the Lower Cretaceous of Laiyang, China // Cretac. Res. Vol.92. P.205-209.

Zherikhin V.V. 1978. [Development and changes of the Cretaceous and Cenozoic faunal assemblages (Tracheata and Chelicerata)] // Trudy Paleontol. Inst. Akad. Nauk SSSR. Vol.165. P.1-198 [in Russian].

Zherikhin V.V. 1990. Fossil insect localities // Rasnitsyn A.P. (ed.). [Late Mesozoic insects of eastern Transbaikalia] Trudy Paleontol. Inst. Akad. Nauk SSSR. Vol.239. P.5-12 [in Russian].

Zherikhin V.V., Mostovski M.B., Vršansky P., Blagoderov V.A., Lukashevich E.D. 1999. The unique Lower Cretaceous locality of Baissa and other contemporaneous insect-bearing sites in the North and West Transbaikalia // Proc. 1st Internat. Palaeoentomol. Conf., Moscow 1998. Bratislava: AMBA projects. P.185-191. 